\title{
Dissolution is not the solution
}

\author{
G. Hossein Almassi, MD
}

From the Division of Cardiothoracic Surgery, Medical College of Wisconsin, Milwaukee, Wis Disclosures: Author has nothing to disclose with regard to commercial support.

Received for publication Dec 2, 2017; accepted for publication Dec 4, 2017; available ahead of print Jan 23, 2018.

Address for reprints: G. Hossein Almassi, MD, Division of Cardiothoracic Surgery, Medical College of Wisconsin, 9200 West Wisconsin Ave, Milwaukee, WI 53226 (E-mail: halmassi@ mcw.edu).

J Thorac Cardiovasc Surg 2018; 155:2020

0022-5223/\$0.00

Published by Elsevier Inc. on behalf of The American Association for Thoracic Surgery https://doi.org/10.1016/j.jtcvs.2017.12.028

With the emergence of coronary artery bypass graft surgery (CABG) in the late 1960s, the management of coronary artery disease (CAD) was ushered into a new era. The 3 major randomized control trials conducted in the $1970 \mathrm{~s}^{1-3}$ established the superiority of CABG over medical therapy in angina relief and survival and led to the establishment of guidelines for $\mathrm{CABG}$ as the preferred procedure for patients with left main coronary stenosis of $\geq 50 \%$ and those with 3-vessel CAD and more so, when associated with depressed left ventricular function. With the introduction of percutaneous coronary balloon angioplasty in 1977 by Gruntzig ${ }^{4}$ and the subsequent development of stent technology, percutaneous coronary intervention (PCI) became an alternative approach for the treatment of CAD. Drugeluting stents (DES), in large part, overcame the shortcomings of the bare metal stents for stent restenosis and narrowed the gap between CABG and PCI for repeat revascularization.

Continued efforts by the industry to improve on the designs of the first-generation DES, and by extension, their long-term performance, led to the introduction of the second-generation DES. As is customary, most of the clinical research trials on newer devices are funded by the industry, with the risk of bias favoring the new devices. The network meta-analysis by Benedetto and colleagues ${ }^{6}$ in this issue of the Journal is a systematic review of 9 randomized control trials on the second-generation DES compared with CABG and first-generation DES in the treatment of unprotected left main coronary stenosis. The authors have methodically outlined the strengths and weaknesses of each trial included. Their detailed analyses and graphic description of the results support their conclusion that the second-generation DES, and specially, the biodegradable biolimus-eluting stents, have not fulfilled the promise of better outcomes compared with CABG or the firstgeneration DES for unprotected left main coronary stenosis.

In the contemporary practice, the management of ischemic heart disease mandates a patient-centered approach by a heart team consisting of a cardiologist and a cardiac surgeon. ${ }^{7,8}$ This in turn means that PCI and CABG should be considered as complementary and not

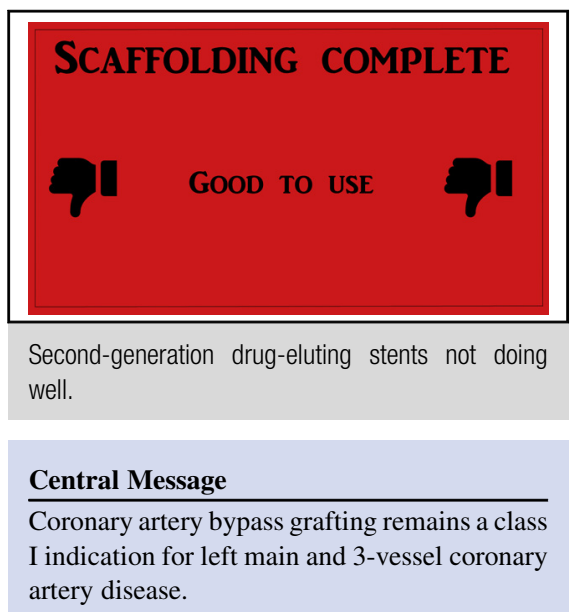

See Article page 2013.

competitive, as seen in a recent publication on stand-alone coronary intervention centers with no on-site cardiac surgery. ${ }^{9}$ After all, CABG stands out as one of the few surgical procedures in which the indications for surgery have remained unchanged over the last 4 decades, with most left main stenoses and 3-vessel CAD having a class I indication in the latest guidelines. ${ }^{8}$ I commend the authors for their important contribution.

\section{References}

1. Murphy ML, Hultgren HN, Detre K, Thomsen J, Takaro T. Treatment of chronic stable angina. A preliminary report of survival data of the randomized Veterans Administration Cooperative study. N Engl J Med. 1977;297:621-7.

2. Long-term results of prospective randomized study of coronary bypass surgery in stable angina pectoris. European Coronary Surgery Study Group. Lancet. 1982;2: 1173-80.

3. Passamani E, Davis KB, Espie MJG, Killip T. A randomized trial of coronary artery bypass surgery. N Engl J Med. 1985;312:1665-71.

4. Gruntzig A. Transluminal dilatation of coronary-artery stenosis. Lancet. 1978; 311:263.

5. Kereiakes DJ, Yeh RW, Massaro JM, Driscoll-Shempp P, Cutlip DE, Steg PG, et al. Stent thrombosis in drug-eluting or bare-metal stents in patients receiving dual antiplatelet therapy. JACC Cardiovasc Interv. 2015;8:1552-62.

6. Benedetto U, Taggart DP, Sousa-Uva M, Biondi-Zoccai G, Di Franco A, Ohmes LB, et al. New-generation stents compared to coronary bypass surgery for unprotected left main disease: a word of caution. J Thorac Cardiovasc Surg. 2018;155:2013-9.e16.

7. Mohr FC, Morice MC, Kappetein AP, Feldman TE, Ståhle E, Colombo A, et al. Coronary artery bypass graft versus percutaneous coronary intervention in patients with three-vessel disease and left main coronary disease: 5-year follow-up of randomised, clinical SYNTAX trial. Lancet. 2013;381:629-38.

8. Fihn SD, Gardin JM, Abrams J, Berra K, Blankenship JC, Dallas AP, et al. 2012 ACCF/AHA/ACP/AATS/PCNA/SCAI/STS guidelines for the diagnosis and management of patients with stable ischemic heart disease. J Am Coll Cardiol. 2012; 60:2564-603.

9. Goel K, Gupta T, Kolte D, Khera S, Fonarow GC, Bhatt DL, et al. Outcomes and temporal trends of inpatient percutaneous coronary intervention at centers with and without on-site cardiac surgery in the United States. JAMA Cardiol. 2017;2: 25-33. 